\title{
Efficacy of Chlorophacinone-treated Wheat Baits for Control of the Northern Pocket Gopher
}

By

Daniel Sullivan and Monty Sullins

MONTANA DEPARTMENT OF AGRICULTURE Environmental Management Division

Technical Services Bureau

Helena, Montana 59620-0205
STATE DOCUMENTS COLLECTION

\section{AUG 91989}

MONTANA STATE LIBRARY

1515 E. Sth AVE.

HELENA, MONTANA 59620

\section{$\underline{\text { Abstract }}$}

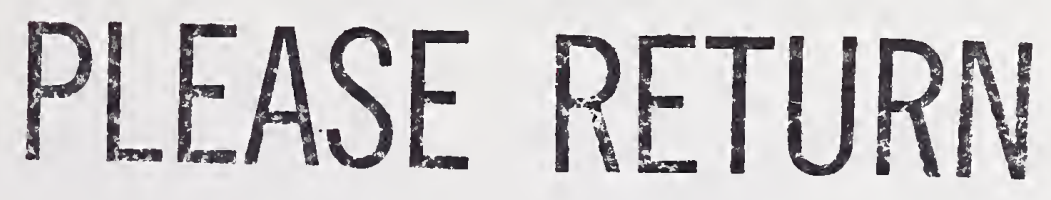

The efficacy of a chlorophacinone-treated (50 ppm) wheat bait was tested on the northern pocket gopher (Thomomys talpoides). Bait was applied by mechanical burrow builder and by a hand application method. The average reduction in gopher activity for the burrow builder and hand baited methods was $77.5 \%$ and $95.5 \%$, respectively, using an active burrow method for efficacy determination. Actual mortality of radiotagged gophers on the burrow builder study sites was $65.0 \% 28$ days after treatment. 


\section{$\underline{\text { Introduction }}$}

Rozol ${ }^{\circledR}$ Pocket Gopher Bait, a product of Chempar, Lipha Chemicals, Inc., is registered by the U.S. Environmental Protection Agency (FIFRA, Section 3) for the control of pocket gophers (Thomomys sp. and Geomys sp.). The current label is registered only for application of the bait by hand methods. Chempar desires to expand the present label to include bait application by mechanical burrow builder. The burrow builder application technique allows a 4-6 fold increase in the acres treated per manhour. Therefore, efficacious results allowing label expansion for mechanical application would be a benefit to agricultural producers controlling pocket gophers on larger crop acreages.

\section{Objective}

The objective of this study was to determine the efficacy of Rozol ${ }^{\circledR}$ Pocket Gopher Bait applied by mechanical burrow builder for control of the northern pocket gopher (Thomomys talpoides).

\section{Study Area}

Five study plots were selected from a uniform, mixed alfalfa-grass hayfield near Kalispell, Flathead County, Montana. The maximum distance between the most distant study plots was approximately $1000 \mathrm{ft}(305 \mathrm{~m})$. Two weeks proceeding the beginning of the study the site was sprinkler irrigated with 3.5 in $(9 \mathrm{~cm})$ of water. Pocket gophers were actively building mounds at the start of the study. The study period began September 26, 1988 and ended November 4, 1988. Temperature ranged from about $17^{\circ} \mathrm{F}$ to $77^{\circ} \mathrm{F}\left(-12^{\circ} \mathrm{C}\right.$ to $\left.25^{\circ} \mathrm{C}\right)$ during the study period and about 1 in $(2.5 \mathrm{~cm})$ of precipitation accumulated from several storms.

\section{Methods}

The bait carrier used in this test was whole grain wheat. The wheat kernels were treated with chlorophacinone, an anticoagulant, at a concentration of $50 \mathrm{ppm}(0.005 \%$ active ingredient by weight).

Bait was applied using a tractor-drawn, mechanical burrow builder (Elston ${ }^{\circledR}$, Sioux Falls, SD). Burrows were constructed at $20 \mathrm{ft}(6 \mathrm{~m})$ intervals. The burrow builder was calibrated to apply $5 \mathrm{lbs}(2.3 \mathrm{~kg})$ of bait per swath acre. Approximately $0.06 \mathrm{oz}(1.75 \mathrm{~g})$ of bait was deposited every 20 in $(50 \mathrm{~cm})$ in the artificial burrow. The artificial burrows were constructed at a depth of $10 \mathrm{in}(25 \mathrm{~cm})$ measuring from the soil surface to the base of the torpedo.

The test bait was also applied by a hand application method at the label recommended rate. This provided a standard with which to compare the efficacy of the burrow builder application. The bait was applied using a probe to locate the pocket gopher tunnel. Approximately $4 \mathrm{oz}(100 \mathrm{~g})$ of bait was placed in the burrow through the probe hole. 
Two to three placements were made per burrow system. Each bait site was marked with a survey flag.

Both tests were replicated once. A buffer, $150 \mathrm{ft}(45 \mathrm{~m})$ wide, was established at the border of each study plot to retard immigration of pocket gophers onto the study plots. The buffer was treated with the same bait and method of application as the plot it bordered.

Time required for bait application and amount of bait applied per acre on each study plot were recorded.

A control plot was monitored for pocket gopher activity in the same manner as the treatment plots. No bait was applied to the control plot.

Efficacy Determination - Active Burrow Counts: Efficacy was measured using active burrow counts to determine reduction in pocket gopher activity. A minimum of 20 active gopher burrows were located per study plot. Pocket gopher activity separated by a distance of 40 or more feet $(12 \mathrm{~m}$ ) was considered a separate burrow system. Burrow systems were opened and any burrow not closed by gopher activity after 48 hours was considered inactive.

At 14 and 28 days after treatment, the burrow systems marked as active during the pretreatment census on each study plots were opened. Each burrow was checked at 24 and 48 hours after opening. Any open burrow that remained open was considered inactive as a result of the bait treatment.

Percent reduction in activity was calculated using the following formula (Henderson and Tilton 1955).

\begin{tabular}{|c|c|c|c|c|}
\hline $\begin{array}{l}\text { Percent } \\
\text { Reduction } \\
\text { in Active }=1\end{array}$ & $\begin{array}{l}\text { Holes Closed } \\
\text { Posttreatment } \\
\text { (Treatment Plot) }\end{array}$ & X & $\begin{array}{c}\text { Holes Closed } \\
\text { Pretreatment } \\
\text { (Control Plot) }\end{array}$ & X 100 \\
\hline Burrows & $\begin{array}{l}\text { Holes Closed } \\
\text { Pretreàtment } \\
\text { (Treatment Plot) }\end{array}$ & $\mathrm{X}$ & $\begin{array}{l}\text { Holes Closed } \\
\text { Posttreatment } \\
\text { (Control Plot) }\end{array}$ & \\
\hline
\end{tabular}

Efficacy Determination - Radio-Tagging: Efficacy was also measured on the burrow builder plots by radio-tagging gophers. On each burrow builder plot, 10 gophers were live-trapped, fitted with radio transmitter collars and released at the site of capture. Movements of the radio-tagged gophers were monitored and their fate was determined during or at the end of the 28 day study period.

Percent mortality of radio-tagged gophers was calculated using the following formula. 


\begin{tabular}{|c|c|c|}
\hline Percent & $\begin{array}{l}\text { No. Gophers } \\
\text { Radio-tagged }\end{array}$ & $\begin{array}{l}\text { No. Radio-tagged Gophers } \\
\text { Alive at Day } 28\end{array}$ \\
\hline Mortality & & $\begin{array}{l}\mathrm{rs} \\
\mathrm{ed}\end{array}$ \\
\hline
\end{tabular}

Following the 28 day posttreatment census, 25 bait placement sites on each hand baited plot were selected randomly and excavated. The amount and condition of bait remaining at each site was recorded.

\section{RESULTS AND DISCUSSION}

Reduction in pocket gopher activity measured by active burrow counts on the burrow builder plots averaged 69.2\% (Range 66.8\% - 67.2\%) and 77.5\% (Range 68.2\% $86.8 \%$ ) at 14 and 28 days after treatment, respectively. Actual mortality of the radiotagged gophers at 28 days after treatment averaged 65\% (13 of 20, Range: 7 of 10 and 6 of 10). Reduction in gopher activity measured by active burrow counts on the hand baited plots averaged 76.9\% (Range:74.6\%-79.2\%) and 95.5\% (Range 90.9\%-100\%) at 14 and 28 days after treatment, respectively.

The average rate of bait application to the burrow builder plots was $5.84 \mathrm{lbs} / \mathrm{ac}$ ( 6.5 $\mathrm{kg} / \mathrm{ha}$ ). This is somewhat higher than the calibrated rate and probably resulted from burrows swathes averaging slightly less than $20 \mathrm{ft}(6 \mathrm{~m})$. The application time averaged $3.42 \mathrm{ac}(1.38 \mathrm{ha})$ per manhour. The average rate of bait application to the hand baited plots was $9.47 \mathrm{lbs} / \mathrm{ac}(10.6 \mathrm{~kg} / \mathrm{ha})$. The application time averaged $0.60 \mathrm{ac}(0.24 \mathrm{ha})$ per manhour.

When we excavated the hand bait placement sites, we found that the bait had been completely removed from $84 \%(42 / 50)$ of the sites sampled. Bait was found undisturbed in the gopher burrow at $12 \%(6 / 50)$ of the sites sampled. Bait at the remaining sites sampled $(4 \%, 2 / 50)$ was found mixed with soil and pushed to the surface. All bait found in the burrow or on the surface had sprouted.

During telemetry monitoring, many of the radio-tagged gophers were repeatedly located at the same site in their individual burrow systems. In 12 cases (Table 1), excavation of this "home" site revealed a nest composed of dry grass. Four of these nests contained bait in quantities ranging from $0.88 \mathrm{oz}$ to $1.65 \mathrm{oz}(25 \mathrm{~g}$ to $50 \mathrm{~g}$ ). Bait found in these nests, even at 28 days after treatment, had not molded and few kernels had sprouted. Bait kernels were swollen and soft enough to pinch in two with a thumbnail. No attempt was made to locate or determine the quantity of bait remaining in artificial burrows or its condition. It is likely that, like the bait found on the hand baited plots, undisturbed bait in the artificial burrows had sprouted.

Bait was found only in the nests of 4 gophers, each of which had died (Table 1). Nests found for 3 other gophers that died contained no bait. For the remaining 6 gophers that died a nest site was not located. Seven radio-tagged gophers were alive 28 days 
TABLE 1. Fate of Radio-tagged Pocket Gophers.

Fate at 28

Nest

Nest

No. Days

Located?

Depth

Bait in

Location

Burrow

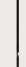

06 Dea

09 Dead

yes

Dead

no

Dead

yes

(in.)

Nest?

of Death

Census

Dead

yes

yes

30

no

Burrow

Inactive

30

48

48

12

Dead

no

31

15

Alive

yes

Dead

no

Alive

no

Alive .

yes

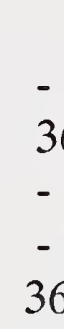

-

no

yes

yes

Surface

Burrow

Nest

Nest

Inactive

Inactive

Inactive

Inactive

Burrow Inactive

Trapped Inactive

Tunnel Inactive

Trapped Active

Trapped

Inactive

20 Dead no

19 Dead no

22 Dead yes

17 Alive no

18. Dead no

23 Alive yes

26

Alive yes

Alive yes

yes

$\begin{array}{ll}- & - \\ - & - \\ 24 & \text { yes } \\ - & - \\ - & -\end{array}$

Burrow

Inactive

Burrow Inactive

Nest

Inactive

Trapped

Active

Burrow

Inactive

32

48

no

Trapped

Active

30

Dead

36

no

Trapped

Active

no

Trapped

Active

yes

Burrow

Inactive

after treatment. Nests for 2 of the surviving gophers were not located. Nests were located for the 5 other survivors. None contained any bait.

One radio-tagged gopher and two unmarked gophers were found dead on the surface. One of the unmarked carcasses was found on a burrow builder plot and the other was found on a hand baited plot.

The reason(s) for survival of 7 of the 20 radio-tagged gophers is unknown. Results of this study show that gophers can find and do collect, in substantial quantity, bait applied by burrow builder. One possible conclusion for the $35 \%$ survival rate may be that the surviving gophers never encountered the artificial burrows. The sample size is small but the fact that 4 of 7 nests located for gophers that died contained bait while none of the 5 nests located for surviving gophers contained bait lends some support to this conclusion. The high efficacy of the hand baited plots indicated that the bait was well ac- 
cepted by gophers when it was placed directly in their burrows. If most gophers on the burrow builder plots encounted the bait and responded to it in the same manner as gophers on the hand baited plots, mortality should have been higher.

It is also possible that the surviving gophers cached but did not consume any bait they encountered. The quality of the burrow builder application may not have been uniform. This may have resulted in collapse of portions of the burrows constructed, burying the bait deposited. The bait, therefore, may not have been readily accessible to some pocket gophers on the burrow builder plots.

Immigrant gophers invading burrow systems after the death of the resident gopher consume food stores left by the previous resident (Tunberg, et al 1984). Gophers that survive a bait treatment, perhaps because they did not encounter the bait initially, may investigate nieghboring systems of pocket gophers that died and feed on any residual bait present. If this results in death of the a portion of the initial survivors, the effective efficacy of the initial bait treatment would be increased. The period of time the bait remains toxic and palatable once placed in food caches or nests is unknown.. In this study, the bait found in the four nests of gophers that died on the burrow builder study plots was in good condition 28 days after application. It appeared palatable and probably retained its toxicity. The bait's longevity will effect its efficacy for killing invading gophers or resident gophers that cache the bait without eating a lethal dose when it is initially encountered.

\section{RECOMMENDATIONS}

Further study is recommended to determine if surviving gophers are finding bait applied by burrow builder. If not, evaluations should be conducted in which spacing and depth of artificial burrows are varied to give maximum efficacy.

Further study is needed to determine the longevity of residual bait stored in food caches and nests and its effectiveness in controlling immigrant or resident gophers feeding on the bait sometime after the bait is cached.

We do not believe that an increase in the active ingredient concentration or bait application rate is necessary to increase efficacy. Observations in this study suggest that gophers survived because they may not have found the bait rather than not being available in sufficient quanity or at a high enough toxicant concentration. Further study might reveal that the rate of bait application can be reduced without affecting efficacy for both burrow builder and hand application methods. This could significantly reduce the cost of pocket gopher control when using the bait tested in this study. 


\section{ACKNOWLEDGEMENTS}

Financial support was provided by the Chempar Products Division of Lipha Chemicals, Inc. and the Montana Department of Agriculture. George Algard and Tom DeLuca reviewed the manuscript. We thank Francis Van Rinsum and his staff of the Flathead County Weed and Rodent District for loan and transport of the burrow builder. Robert Sanders provided use of his tractor and access to his property. We are grateful to Mr. Sanders for sharing with us his many years of experience in pocket gopher management and his welding skill in repair of the burrow builder which saved us many hours of down time.

\section{LITERATURE CITED}

Henderson, C.F. and W. Tilton 1955. Test with acaricides against the brown mite. J Econ Entom. 48(2):157-161.

Tunberg, A.D., W.E. Howard and R.E. Marsh 1984. A new concept in pocket gopher control. Proc. Vertebrate Pest Conf. 11:7-16. Univ. of California, Davis, CA. 
